Pobrane z czasopisma Annales $\mathrm{H}$ - Oeconomia http://oeconomia.annales.umcs.pl

Data: 26/04/2023 14:39:20

DOI:10.17951/h.2020.54.2.89-101

\begin{tabular}{lcc}
\hline \multicolumn{1}{c}{ A N N A L E S } \\
UNIVERSITATIS MARIAE CURIE-SKŁODOWSKA \\
LUBLIN - POLONIA \\
VOL. LIV, 2 & SECTIOH H \\
\hline
\end{tabular}

\author{
ANNA PLUSKOTA \\ anna.pluskota@uni.lodz.pl \\ University of Lodz. Faculty of Economics and Sociology \\ 3/5 Polskiej Organizacji Wojskowej St., 90-255 Lodz \\ ORCID ID: https://orcid.org/0000-0002-2566-3420 \\ MONIKA BOLEK \\ monika.bolek@uni.lodz.p1 \\ University of Lodz. Faculty of Economics and Sociology \\ 3/5 Polskiej Organizacji Wojskowej St., 90-255 Lodz \\ ORCID ID: https://orcid.org/0000-0001-9376-1105 \\ RAFAŁ WOLSKI \\ rafal.wolski@uni.lodz.pl \\ University of Lodz. Faculty of Economics and Sociology \\ 3/5 Polskiej Organizacji Wojskowej St., 90-255 Lodz \\ ORCID ID: https://orcid.org/0000-0002-4001-2415
}

\title{
Liquidity - Profitability Relationship Analysed with the Granger Causality Test on the Example of the Warsaw Stock Exchange
}

Keywords: liquidity; profitability; causality

JEL: G30

How to quote this paper: Pluskota, A., Bolek, M., \& Wolski, R. (2020). Liquidity - Profitability Relationship Analysed with the Granger Causality Test on the Example of the Warsaw Stock Exchange. Annales Universitatis Mariae Curie-Skłodowska, sectio H-Oeconomia, Vol. 54, No. 2. 


\begin{abstract}
Theoretical background: The liquidity - profitability relationship is widely analysed in the literature. The surveys are based on different ratios, and different results as far as the sign of this relationship is concerned. The theory says that liquidity affects profitability but there are some findings suggesting that this relationship is reversed, namely profitability affects liquidity.

Purpose of the article: The purpose of this paper is to compare the main and alternative markets of the Warsaw Stock Exchange according to the mutual influence of financial liquidity and profitability. The companies listed on those two markets are in a different stage of development and it is expected that the direction of the mutual impact of liquidity and profitability will be opposite.

Research methods: The Granger causality test is applied for the data representing the financial liquidity and profitability ratios.

Main findings: It was found that the mutual impact of liquidity and profitability is not opposite and profitability has a greater influence on financial liquidity in case of both markets which means that although the companies listed on the main and alternative WSE markets differ with regard to the stage of development, their management goals are the same.
\end{abstract}

\title{
Introduction
}

Financial liquidity and profitability represent strategies of business and this relationship can be seen from the perspective of the ability to pay obligations on time or profit maximization. The first option represents the conservative strategy and assumes that the liquidity policy is more important than profitability maximization, meaning that in the first place, the company focuses on the ability to pay its liabilities in order not to be exposed to bankruptcy, thereby reducing the specific risk of its performance. In practice, to support this policy, the company invests more capital in the current assets encouraging its operations and reducing the profitability. In the second option the main goal of the company is to generate the highest possible income, which means that the business entity will first pay attention to profitability maximisation and only then to the ability to pay its obligations on time. The lower financial liquidity in most cases leads to an improvement in the company's profitability, which is the main issue of the aggressive strategy. In their activity, these enterprises use short-term liabilities financing the business in a higher degree, which is relatively cheaper when compared to long-term loans. This is reflected in the fact that, compared to conservative policy, the company is able to generate more profits from the same amount of capital.

The purpose of this article is to analyse the relationship between financial liquidity and profitability, taking into account the directions of their interaction. Companies listed on the main and alternative markets may be managed in a different way because they are in different stages of development characterised by specific goals (Bolek, 2018). It is assumed that there is a difference in the strategy performed by companies in the two groups taken into consideration, which means that the mutual influence between financial liquidity and profitability may be characterised by a different direction.

In the survey, the Polish companies traded on the main and alternative NewConnect markets at the Warsaw Stock Exchange are taken into consideration. The paper 
is divided into the following sections: first, there is a literature review, then data and methods employed in the study are provided. Next sections refer to the presentation of results, discussion, and conclusions.

\section{Liquidity - profitability relationship. Literature review}

The relationship between financial liquidity and profitability is an important issue in the field of financial management and it should be discussed in the context of factors related to the growth of enterprises because profitability and financial liquidity affect the growth of business and, according to the theory, liquidity affects profitability. Szczepaniak (1996) claims that in the area of finance, the factors that are most often presented as important in determining the current and future condition of a company are profitability and financial liquidity. It can be stated that the relationship between liquidity and profitability depends on the strategies implemented by the company such as the strategy of managing current assets or net working capital, strategies implemented towards clients and suppliers, as well as product and service development policy.

The relationship between liquidity and profitability can be presented as described by Gajdka and Walińska (2008) and visualized in Figure 1.

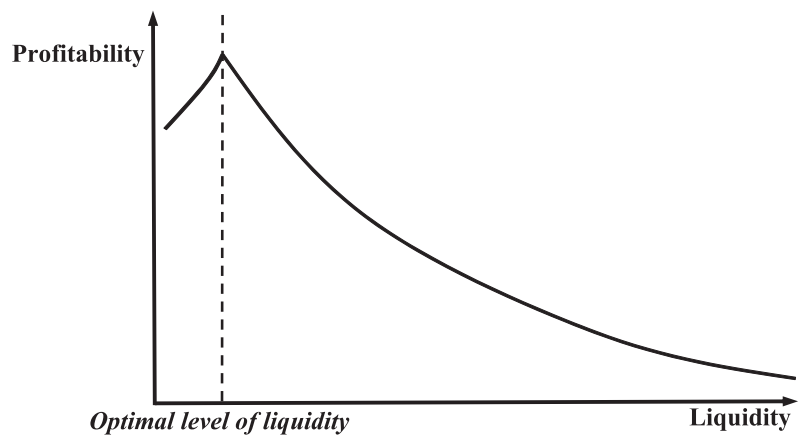

Figure 1. The relationship between liquidity and profitability of an enterprise Source: (Gajdka \& Walińska, 2008, p. 467).

Studies related to the analysis of the relationship between financial liquidity and profitability constitute a large part of the literature devoted to the problem of maximizing the value of an economic entity and take into account various indicators. One of the first studies on liquidity and profitability was published by Smyth, Samuels, and Tzoannos (1972). The authors referred to the relationship between liquidity and profitability, also taking into account the size of the company and its innovations. 
In that study, liquidity was interpreted only in a traditional manner, related to the ability to pay liabilities.

There are more findings in the field of the liquidity - profitability relationship. Research devoted to the analysis of the correlation between liquidity and profitability was presented by Jose, Lancaster, and Stevens (1996) who stated that an aggressive working capital management policy leads to an increase in profitability. In that survey, the liquidity was measured by the cash conversion cycle (CCC), whereas profitability - by ROA and ROE with gross profit base. Gill, Biger, and Mathur (2010) found that there was a negative relationship between the receivables turnover and efficiency measured by the gross margin, and a positive relationship between CCC and the gross margin. Shin and Soenen (1998) analysed the relationship between liquidity and profitability and found that there was a negative relationship between $\mathrm{CCC}$ and profitability. At the same time, the positive relationship between CCC and the gross margin suggested that the longer CCC, the higher the company's profitability. Lyroudi and Lazaridis (2000) presented a liquidity and profitability analysis on the food market in Greece and found that there was a positive relationship between liquidity expressed as $\mathrm{CCC}$ and profitability measured by ROA and net profit margin. Deloof (2003) analysed the relationship of liquidity and profitability on the Belgian market and stated that managers could increase profitability by reducing the level of receivables and liabilities and, thus, accelerate their turnover.

Garcia-Teruel and Martinez-Solano (2007) analysed the relationship between working capital and profitability among enterprises belonging to the SME sector in Spain. The authors concluded that there was a negative relationship between profitability and inventory and receivables conversion cycles indicating that managers could increase the value of an enterprise by reducing inventory and receivables. As a result of the study, the relationship between CCC and ROA was identified as negative.

Most foreign surveys indicate the existence of a negative relationship between liquidity and profitability, and CCC is the most often used measure of liquidity in those surveys. The proper management of working capital and liquidity cannot only protect the company from financial distress but it can also create a competitive advantage. Therefore, the accurate measurement of liquidity and its consequences for the value of a firm is a major issue for managers.

Michalski (2010) claims that knowing the necessary level of cash that enables repayment of current debts, the entity determines the structure of current assets and sources of financing using one of three financial policies: conservative, aggressive and moderate. It is also possible to determine the optimum level of current assets based on the analysis of operating activities and matching liabilities, which is possible only among enterprises with a competitive advantage on the market. There are other proposals how to distinguish strategies in the company. Due to the profitability, the demand for current assets, as well as the need for capital, one can distinguish even 11 different strategies for managing working capital (Talonpoika, Kärri, Pirttilä, \& Monto, 2016). The direction of the impact between the profitability and liquidity 
can indicate the strategy the company performs to fulfill the goal related to the value maximization through risk reduction or/and profit maximization.

In Poland, many analyses of liquidity and profitability relationships were carried out, too. This relationship can be positive or negative, or it may not appear in the survey results. At first, the positive results of research will be discussed. Paździor (2009) presented a positive relationship between the measure of current liquidity and profitability on sales and equity, whereas Wyrobek (2007) found that the correlation between the static liquidity measures and return on equity was positive basing on listed companies' results in 1997-2004. Hodun (2010) found a positive relationship between liquidity and profitability and came to the conclusion that if enterprises performed a conservative or moderately conservative policy of managing capital, they could get maximum return. Dresler (2014) analysed the relationship between liquidity and profitability of companies from twelve different sectors. The results indicated a strong positive relationship between various static liquidity ratios and profitability ratios. Positive correlation occurred in most of the analysed sectors.

The negative correlation between liquidity and profitability can also be found in the Polish literature. Guzik (2006) indicated a negative correlation between liquidity and profitability and treated liquidity as only one of many determinants affecting the profitability of enterprises, whereas Waściński and Kruk (2010) conducted a study on companies listed on the Warsaw Stock Exchange concluding that there was a negative relationship between liquidity and profitability. Bieniasz and Gołaś (2011) presented the results of working capital management efficiency tests in small, medium and large enterprises of the food industry in Poland. The working capital management efficiency was assessed using the inventory, receivables, payables and CCCs in relation to the rates of return on non-financial assets. Studies showed that in enterprises where working capital cycles were the shortest, relatively higher return on assets was obtained. Wawryszuk-Misztal (2007) also run liquidity and profitability studies on a group of companies listed on the WSE and assessed the relationship between receivables, inventory, liabilities, operating cycle and CCCs with ROE and ROA profitability ratios. She stated that a longer operating cycle negatively affected profitability. A negative correlation also took place in the case of liabilities turnover cycle and profitability. In addition, Stefański (2012), analysing the Polish market, stated that there was a negative relationship between CCC and profitability and therefore higher profitability occurred with faster recovery of receivables and decreases with the longer recovery period.

Among the various works regarding the issue of the relationship between financial liquidity and profitability, some statements can be pointed out indicating that there is no correlation between liquidity and profitability. Sometimes the results obtained are divergent, ambiguous or contradictory to the classical theory of business economics. Such a relationship between liquidity and profitability of an enterprise was presented by studies carried out by Keller and Pastusiak (2014). Their findings indicated a very low level of relationship between the return on assets and quick and current ratios. In case of ROE, this relationship turned out to be ten times lower, al- 
most zero. After using more precise research methods and obtaining the final version of the model, the results confirmed the co-directional relationship between liquidity and profitability. Wypych (2010) indicated that the correlation between liquidity and profitability occurred in his findings, however, it was so insignificant that it could be concluded that any changes in the level of liquidity could not explain changes in the level of profitability in the company.

Zuba (2009) indicated that the discrepancy in liquidity and profitability in most cases is noticeable in the short term and a positive correlation can be realized in the long term. In addition, the drawback underlying the analysis of the relationship of liquidity and profitability is taking into account both phenomena independently, in most cases without attempting to highlight mutual interdependencies. This is the reason for conducting the research in order to find the mutual relationship between liquidity and profitability and their directions.

The relationship between financial liquidity and the associated net working capital and profitability, even though it has been examined many times, is still not fully explained. The discrepancy in results may be related to the choice of different measures representing liquidity and profitability. This problem may also depend on the sector in which the enterprise operates but also on the development phase. Findings in the literature show that companies in the growing stage of development should be characterized by higher liquidity that supports their growth (Bolek, 2018). There are different possible strategies that companies can perform and the following survey will show whether there is any difference between strategies performed by developed and young, growing companies.

\section{Methods and data}

Research hypotheses are verified by the Granger causality test, which enables to draw the conclusions whether there is a relation between two variables (Syczewska, 2014). Below there are presented formulas for the Granger causality tests. If there are two time series $X$ and $Y$, the paired model is as follows:

$$
\begin{aligned}
& Y_{t}=\sum_{n=1}^{p} A_{n} X_{(t-p)}+\sum_{n=1}^{p} B_{n} Y_{(t-p)}+C Z_{t}+E_{t} \\
& X_{t}=\sum_{n=1}^{p} A_{n}^{\prime} Y_{(t-p)}^{\prime}+\sum_{n=1}^{p} B_{n}^{\prime} X_{(t-p)}^{\prime}+C^{\prime} Z_{t}+E_{t}^{\prime}
\end{aligned}
$$

where:

$X_{t}$ and $Y_{t}$ represent two time series at time $t$,

$X_{(t-p)}$ and $Y_{(t-p)}$ represent the time series at time t-p,p representing the number of lagged time points (order), 
$A_{n}$ and $A_{n}^{\prime}$ are signed path coefficients,

$B_{n}$ and $B_{n}^{\prime}$ are autoregression coefficients,

$E_{t}$ and $E_{t}^{\prime}$ are residual.

The following set of variables, taken directly from the database, are used in the study:

- NPM (net profit margin),

- ROE (the return on equity),

- CR (current liquidity ratio),

- QR (quick ratio),

- CCC (cash conversion cycle).

The data is taken from Notoria Database for the years 2002-2017. The surveys are presented separately for companies listed on two markets: the WSE main market and the NewConnect alternative market.

\section{Results}

In the following section, the descriptive statistics of data and Granger causality tests results are presented, respectively.

\section{Descriptive statistics}

First, the statistical analysis of variables is presented in Tables 1 and 2 for the main and alternative markets of WSE, respectively.

Table 1. Descriptive statistics for the WSE main market

\begin{tabular}{|l|c|c|c|c|c|}
\hline Variable & Mean & Median & S.D. & Min. & Max \\
\hline NPM & 0.0537 & 0.0414 & 0.310 & -1.98 & 1.93 \\
\hline ROE & 0.0657 & 0.0687 & 0.260 & -1.97 & 1.84 \\
\hline CR & 2.0800 & 1.53 & 1.68 & 0.00289 & 9.92 \\
\hline QR & 0.8210 & 0.244 & 1.50 & 0.000023 & 9.96 \\
\hline CCC & 16.7000 & 15.4 & 121.00 & -835. & 799. \\
\hline
\end{tabular}

Source: Authors' own study.

Table 2. Descriptive statistics for the NewConnect alternative market

\begin{tabular}{|l|c|c|c|c|c|}
\hline Variable & Mean & Median & S.D. & Min. & Max \\
\hline NPM & -0.0418 & 0.0231 & 0.411 & -2.00 & 1.99 \\
\hline ROE & -0.0074 & 0.0384 & 0.415 & -1.96 & 1.85 \\
\hline CR & 2.4000 & 1.68 & 2.07 & 0.0130 & 9.96 \\
\hline QR & 1.1700 & 0.367 & 1.92 & -0.238 & 9.80 \\
\hline CCC & 39.7000 & 15.1 & 166.00 & -915.00 & 0.000022 \\
\hline
\end{tabular}

Source: Authors' own study. 
Descriptive statistics present mean, media, standard deviation, minimum and maximum data in each group of companies. Companies on the alternative NewConnect market are generating negative profits and their liquidity policy is slightly more conservative than in the companies traded on the WSE main market, whose profitability is positive. Comparing standard deviations for all variables, it can be seen that they are greater for the NewConnect market than for the WSE main market companies. An analogous situation applies to the minimum and maximum values, because the variables on the NewConnect market are characterized by a larger dispersion of data. Companies listed on the NewConnect market are smaller and their performance is related to the higher risk, while the companies listed on the WSE main market are mature and their performance is less volatile.

\section{Granger causality test (1 delay period)}

The Granger causality tests for selected variables are presented below for WSE main and alternative NewConnect markets. In Table 3, by means of the Granger test for the WSE main market, the analysis of the impact of liquidity on profitability is presented.

Table 3. The impact of liquidity on profitability (WSE main market, $n=3,114$ )

\begin{tabular}{|l|c|c|c|}
\hline Variable & Coefficient & $t$-Student & Significance \\
\hline CR->ROE & -0.000276653 & -0.1188 & - \\
\hline QR->ROE & -0.00434157 & -1.715 & $*$ \\
\hline CCC->ROE & $-2.52393 \mathrm{e}-05$ & -0.7248 & $* * *$ \\
\hline CR->NPM & 0.00992144 & 3.312 & $* *$ \\
\hline QR->NPM & 0.00773788 & 2.190 & - \\
\hline CCC->NPM & $1.79663 \mathrm{e}-05$ & 0.4515 & - \\
\hline
\end{tabular}

Note: It is assumed that the parameter is statistically significant for every $p$-value smaller than 0.1 , for increasing confidence intervals of $1 \%(* * *), 5 \%(* *)$ and $10 \%(*)$, respectively.

Source: Authors' own study.

As part of the analysis of the impact of liquidity on profitability on the WSE main market presented in Table 3, the following pairs of variables were analysed:

- impact of CR on ROE: not significant,

- impact of quick ratio QR on ROE: there is a negative relationship,

- impact of CCC on ROE: not significant,

- impact of CR on the net profit margin: there is a positive relationship,

- impact of QR on the net profit margin: there is a positive relationship,

- impact of CCC on the net profit margin: not significant.

The impact of liquidity on profitability has not been significantly confirmed in 3 out of 6 cases. In Table 4, using the Granger test for WSE main market, the analysis of the impact of profitability on liquidity is presented. 
Pobrane z czasopisma Annales H - Oeconomia http://oeconomia.annales.umcs.pl Data: 26/04/2023 14:39:20

LIQUIDITY - PROFITABILITY RELATIONSHIP ANALYSED WITH THE GRANGER CAUSALITY TEST...

Table 4. The impact of profitability on liquidity (WSE main market, $n=3,114$ )

\begin{tabular}{|l|c|c|c|}
\hline Variable & Coefficient & $t$-Student & Significance \\
\hline ROE->CR & 0.321109 & 3.446 & $* * *$ \\
\hline ROE->QR & 0.0551427 & 0.6488 & $* * *$ \\
\hline ROE->CCC & 24.6708 & 3.252 & $* *$ \\
\hline NPM->CR & 0.217277 & 2.533 & $*$ \\
\hline NPM->QR & 0.136833 & 1.863 & $* * *$ \\
\hline NPM->CCC & 30.5290 & 3.199 & - \\
\hline
\end{tabular}

It is assumed that the parameter is statistically significant for every $p$-value smaller than 0.1 , for increasing confidence intervals of $1 \%(* * *), 5 \%(* *)$ and $10 \%(*)$, respectively.

Source: Authors' own study.

As part of the analysis of the impact of profitability on liquidity on the WSE market, the following pairs of variables were selected:

- impact of ROE on CR: there is a positive relationship,

- impact of ROE on QR: not significant,

- impact of ROE on CCC: there is a positive relationship,

- impact of net profit margin on CR: there is a positive relationship,

- impact of net profit margin on QR: there is a positive relationship,

- impact of net profit margin on CCC: there is a positive relationship.

The impact of profitability on liquidity in the case of the WSE main market has been confirmed in 5 out of 6 cases. In Table 5, by means of the Granger test for the NewConnect alternative market, the analysis of the impact of liquidity on profitability is presented.

Table 5. The impact of liquidity on profitability (NewConnect alternative market, $\mathrm{n}=1,558$ )

\begin{tabular}{|l|c|c|c|}
\hline Variable & Coefficient & $t$-Student & Significance \\
\hline CR->ROE & -0.00257794 & -0.6110 & - \\
\hline QR->ROE & 0.00304128 & 0.7192 & $*$ \\
\hline CCC->ROE & -0.000425995 & -5.708 & - \\
\hline CR->NPM & 0.00348701 & 0.7871 & $* *$ \\
\hline QR->NPM & 0.00995511 & 2.103 & $* * *$ \\
\hline CCC->NPM & -0.000210275 & -2.811 & $* *$ \\
\hline
\end{tabular}

It is assumed that the parameter is statistically significant for every $p$-value smaller than 0.1 , for increasing confidence intervals of $1 \%(* * *), 5 \%(* *)$ and $10 \%(*)$, respectively.

Source: Authors' own study.

As part of the analysis of the impact of liquidity on profitability on the NewConnect market, the following pairs of variables were selected:

- impact of CR on ROE: not significant,

- impact of QR on ROE: not significant,

- impact of CCC on ROE: there is a negative relationship,

- impact of CR on the net profit margin: not significant,

- impact of QR on the net profit margin: there is a positive relationship, 
- impact of CCC on the net profit margin: there is a negative relationship.

The impact of liquidity on profitability on the NewConnect market is not very clear, as it is confirmed by 3 out of 6 cases examined. In Table 6, using the Granger test for the NewConnect alternative market, the analysis of the impact of profitability on liquidity is presented.

Table 6. The impact of profitability on liquidity (NewConnect alternative market, $\mathrm{n}=1,558$ )

\begin{tabular}{|l|c|c|c|}
\hline \multicolumn{1}{|c|}{ Variable } & Coefficient & $t$-Student & Significance \\
\hline ROE $\rightarrow$ CR & 0.569582 & 5.284 & $* * *$ \\
\hline ROE $->$ QR & 0.343521 & 3.458 & $* * *$ \\
\hline ROE $->$ CCC & 26.7552 & 2.551 & $* * *$ \\
\hline NPM $\rightarrow$ CR & 0.470248 & 4.087 & $* * *$ \\
\hline NPM $\rightarrow$ QR & 0.387405 & 3.677 & $* *$ \\
\hline NPM $\rightarrow$ CCC & 38.8534 & 2.480 & $* *$ \\
\hline
\end{tabular}

It is assumed that the parameter is statistically significant for every $p$-value smaller than 0.1 , for increasing confidence intervals of $1 \%(* * *), 5 \%(* *)$ and $10 \%(*)$, respectively.

Source: Authors' own study.

As part of the analysis of the impact of profitability on liquidity on the NewConnect market, the following pairs of variables were selected:

- impact of ROE on CR: there is a positive relationship,

- impact of ROE on $\mathrm{QR}$ ratio: there is a positive relationship,

- impact of ROE on CCC: there is a positive relationship,

- impact of net profit margin on CR: there is a positive relationship,

- impact of net profit margin on QR: there is a positive relationship,

- impact of net profit margin on CCC: there is a positive relationship.

Analysis of the impact of profitability on liquidity on the NewConnect market shows that such a relationship occurs and is statistically significant.

\section{Discussion}

The research results on WSE markets bring interesting conclusions. Companies listed on the WSE main market are larger according to the requirements of the exchange regarding the size. Companies listed on the NewConnect alternative market are younger and smaller. Both groups of companies can behave in a different way when the strategy of management is taken into consideration because they can focus on different goals. Companies listed on the NewConnect market are characterized by a higher degree of risk than companies listed on the main market and it can be related to the different approach to the value maximization in those groups of companies. Since the young companies tend to be riskier investments, the value maximization could be related to the risk reduction and a more conservative approach to liquidity, 
which can support the growth of young entities as it was found by Bolek (2018). The average values of liquidity ratios show that the liquidity strategy of companies listed on the NewConnect market is more conservative than the policy performed by mature companies, with the accompanying negative income and profitability.

The Granger causality tests brought some interesting results regarding the mutual relationship between profitability and liquidity. Liquidity affects profitability only in 3 cases on 6 on the WSE main market, whereas profitability affects liquidity in the 5 out of 6 cases. In the group of mature companies listed on the WSE market, the influence of profitability on liquidity is higher than the influence of liquidity on profitability. It can be concluded that profitability is the goal of the companies under the corporate governance requirements of investors. $\mathrm{QR}$ affects the $\mathrm{ROE}$ in a negative way, but the impact on NPM is positive in case of CR and QR, while CCC is not relevant. In case of profitability affecting the liquidity, these impacts are positive on the WSE main market and the only insignificant relationship is between ROE and QR.

On the NewConnect market, the situation is similar regarding the impact of liquidity on profitability, and the impact of profitability on liquidity is significant in every case taken into consideration. The profitability is influencing the liquidity rather than liquidity is influencing the profitability. CCC significantly affects ROE and NPM in a negative way and QR affects NPM in a positive way. Profitability affects liquidity in a positive way in every case.

\section{Conclusions}

Companies listed on the NewConnect alternative market are characterized by higher values of risk measures than companies traded on the main WSE market. Such results affect the expectations of investors and suggest that those companies may have different goals. It was assumed that the direction of liquidity - profitability relationship will be opposite on the markets taken into consideration. The results brought different answers than expected and it was found that on both markets the influence of profitability on liquidity is higher than the influence of liquidity on profitability. It is not according to the theory that says that liquidity affects profitability. It does, but the opposite statement is true as well. Moreover, it is stronger. The findings show that, according to the Granger causality tests, the influence of profitability on liquidity is higher than the influence of liquidity on profitability. Additionally, both mature and growing companies, focus on profitability and value maximization.

\section{References}

Bieniasz, A., \& Gołaś, Z. (2011). Sprawność zarządzania kapitałem obrotowym i jej wpływ na rentowność małych, średnich i dużych przedsiębiorstw przemysłu spożywczego w Polsce. Journal of Agribusiness and Rural Development, 4(22). 
Bolek, M. (2018). Determinanty wzrostu przedsiębiorstw na rynku kapitałowym. Łódź: Wydawnictwo Uniwersytetu Łódzkiego.

Deloof, M. (2003). Does working capital management affect profitability of Belgian firms? Journal of Business Finance \& Accounting, 30(3-4). doi:10.1111/1468-5957.00008

Dresler, Z. (2014). Rentowność przedsiębiorstw w Polsce. Kraków: Wydawnictwo Uniwersytetu Ekonomicznego.

Gajdka, J., \& Walińska, E. (2008). Zarządzanie finansowe teoria i praktyka, t. 2. Warszawa: Fundacja Rozwoju Rachunkowości w Polsce.

García-Teruel, P.J., \& Martínez-Solano, P. (2007). Effects of working capital management on SME profitability. International Journal of Managerial Finance, 3(2). doi:10.1108/17439130710738718

Gill, A., Biger, N., \& Mathur, N. (2010). The relationship between working capital management and profitability: Evidence from the United States. Business and Economics Journal, 10.

Guzik, B. (2006). Statystyczne metody badania związków między rentownością a płynnością bankową. Badania Operacyjne i Decyzje, 3-4.

Hodun, M. (2010). Rentowność przedsiębiorstw przemysłowych w zależności od strategii zarządzania kapitałem obrotowym netto. Zeszyty Naukowe SGGW, Ekonomika i Organizacja Gospodarki Żywnościowej, 81 .

Jose, M.L., Lancaster, C., \& Stevens, J.L. (1996). Corporate returns and cash conversion cycles. Journal of Economics and Finance, 20(1). doi:10.1007/BF02920497

Keller, J., \& Pastusiak, R. (2014). Płynność a efektywność funkcjonowania przedsiębiorstwa na przykładzie spółek notowanych na GPW. Acta Universitatis Lodziensis, Folia Oeconomica, 2(300).

Lyroudi, K., \& Lazaridis, Y. (2000). The cash conversion cycle and liquidity analysis of the food industry in Greece. Retrieved from http://papers.ssrn.com/sol3/papers.cfm?abstract_id=236175, doi:10.2139/ssrn.236175

Michalski, G. (2010). Strategicznezarzadzanie płynnościa finansowa w przedsiębiorstwie. Warszawa: $\mathrm{CeDeWu}$.

Paździor, A. (2009). Zależność między płynnością a rentownością spółek notowanych na GPW w Warszawie. In M. Sierpińska (red.), Zarzadzanie finansami we wspótczesnych przedsiębiorstwach .Warszawa: Vizja Press \& IT.

Shin, H.H., \& Soenen, L. (1998). Efficiency of Working Capital and Corporate Profitability. Financial Practice and Education, 8.

Smyth, D.J., Samuels, J.M., \& Tzoannos, J. (1972). Patents, profitability, liquidity and firm size. Applied Economics, 4(1). doi:10.1080/00036847200000037

Stefański, A. (2012). Zależność między okresem konwersji gotówki a rentownością - wyniki badań. Ekonomika i Organizacja Gospodarki, 97.

Syczewska, E.M. (2014). Przyczynowość w sensie Grangera - wybrane metody. Metody Ilościowe w Badaniach Ekonomicznych, 15(4).

Szczepaniak, P. (1996). Relacje między płynnością a rentownością finansową. Finanse i Bankowość, 3.

Talonpoika, A.M., Kärri, T., Pirttilä, M., \& Monto, S. (2016). Defined strategies for financial working capital management. International Journal of Managerial Finance, 12(3). doi:10.1108/IJMF-11-2014-0178

Waściński, T., \& Kruk, M. (2010). Analiza powiązań pomiędzy rentownością i płynnością spółek branży cukierniczej notowanych na GPW w Warszawie. Zeszyty Naukowe Akademii Podlaskiej w Siedlcach, Seria: Administracja i Zarządzanie, 84.

Wawryszuk-Misztal, A. (2007). Zależność między zarządzaniem kapitałem obrotowym netto, a rentownością na przykładzie spółek notowanych na Giełdzie Papierów Wartościowych w Warszawie. Annales Universitatis Mariae Curie-Sktodowska, Oeconomia, XLI(20).

Wypych, M. (2010). Płynność finansowa jako determinanta zmian poziomu rentowności przedsiębiorstw w okresie spowolnienia gospodarczego. In J. Sobiech (red.), Kierunki zmian w finansach przedsiębiorstwa. Zeszyty Naukowe Uniwersytetu Ekonomicznego w Poznaniu, 142. 
Pobrane z czasopisma Annales $\mathrm{H}$ - Oeconomia http://oeconomia.annales.umcs.pl Data: 26/04/2023 14:39:20

LIQUIDITY - PROFITABILITY RELATIONSHIP ANALYSED WITH THE GRANGER CAUSALITY TEST...

Wyrobek, J. (2007). Zależność pomiędzy płynnością, rentownością i upadłością firm. Wyniki badań empirycznych dla polskich spółek giełdowych. In W. Pluta (red.), Zarządzanie finansami firm-teoria i praktyka. Prace Naukowe, 1152. Wrocław: Wydawnictwo Akademii Ekonomicznej im Oskara Langego.

Zuba, M. (2009). Związek rentowności i płynności finansowe przedsiębiorstwa. Zeszyty Naukowe Wyższej Szkoły Ekonomii i Innowacji w Lublinie, Seria: Ekonomia, 1. 